\title{
Po co czytać Harolda Blooma i jak, czyli o kanoniczności krytyka
}

\section{Reading Harold Bloom - What For and How? On Canonicality of the Critic}

Abstract: The relationship between the idea of Harold Bloom's literary canon and the status of his own critic's oeuvre is discussed in the article. Diverse topics and literary styles cultivated by the author of The Anxiety of Influence were characterised and evaluated from the perspective of their canonicality understood as an aesthetic and social value. According to Bloom himself, the canonical texts also offer the spiritual value with help of such tools as irony and metaphor, provoking the readers to assess their own condition. The article presents the Polish reception of Harold Bloom's texts and examines the presence of Polish literature in the Western literary canon designed by him. Its weak representation demands response of the critics who could propose their own list of literary works based on criteria equally strong as Bloom's ones but overcoming his oftentimes colonial, patriarchal and exclusionary influence.

Keywords: literary canon, Harold Bloom, canonicality, the anxiety of influence, canon of Polish literature

Streszczenie: W artykule analizie poddane zostają relacje pomiędzy koncepcją kanonu literackiego Harolda Blooma a statusem jego własnej twórczości krytycznej. Różne tematy i style pisarstwa uprawianego przez autora Lęku przed wptywem zostały scharakteryzowane i ocenione pod kątem ich kanoniczności, rozumianej jako wartość estetyczna i społeczna. Według samego Blooma teksty kanoniczne oferują także wartość duchową, za pomocą takich narzędzi jak ironia i metafora, prowokując czytelników do poznawania własnej kondycji. Artykuł zdaje także sprawę z polskiej recepcji pism Blooma oraz porusza kwestię sposobu, w jaki literatura polska jest obecna w zaprojektowanym przez niego zachodnim kanonie. Jej słaba reprezentacja domaga się odpowiedzi krytyków, którzy mogliby zaproponować własną listę dzieł, według kryteriów podobnie mocnych jak te Bloomowskie, lecz przezwyciężających jego - niejednokrotnie kolonizatorski, patriarchalny i ekskluzywistyczny - wpływ.

Słowa kluczowe: kanon literacki, Harold Bloom, kanoniczność, lęk przed wpływem, kanon literatury polskiej 
Czy Harold Bloom, umierając, dołączył do grona Martwych Białych Mężczyzn ${ }^{1}$, których wypada czytać głównie z uwagi na ich przywilej? Byłoby to głęboko ironiczne, skoro należał do apologetów tradycyjnego kanonu - tworzonego przeważnie przez takich właśnie autorów - broniąc jego estetycznych i duchowych wartości przeciwko feministycznym czy postkolonialnym krytykom. Jego monumentalne dzieło, obejmujące ponad pięćdziesiąt książek i setki prac edytorskich, mogło powstać dzięki prestiżowej posadzie na Yale University, rzadko przyznawanej kobietom ${ }^{2}$, a zapewniającej między innymi wieloletni dostęp do jednej z najlepszych bibliotek na świecie Sterling Memorial Library. Można też podejrzewać, że jako rzecznik głównie białych mężczyzn (cóż z tego, że - w jego własnym mniemaniu - ta zbieżność była przypadkowa, a przyczyny zasadniczo estetyczne), był tym chętniej promowany przez to grono, co napędzało machinę wpływu. Jego nadzwyczajną pisarską płodność można natomiast tłumaczyć cechującym go (a premiowanym u mężczyzn) temperamentem polemicznym, czasem graniczącym z arogancją. Choć wyliczam te argumenty z pewną satysfakcją, znajduję także wiele poważnych powodów, by czytać teksty Harolda Blooma i cieszy mnie publikacja jego kolejnych książek w języku polskim.

Wydawnictwo Aletheia opublikowało ostatnio trzy jego książi: Jak czytać i po co, Zachodni kanon i (nieco wcześniej) Księge J³. To bardzo potrzebne uzupełnienie polskojęzycznej półki „bloomianów”, na której dotąd więcej było pozycji omawiających dzieło krytyka i inspirowanych nim niż przekładów tekstów jego autorstwa ${ }^{4}$. Pamiętajmy, że słynny Lęk przed wptywem został napisany w roku $1973^{5} \mathrm{i}$ od tego czasu wydarzyło się w pisarstwie Blooma sporo rzeczy ciekawych, różnorodnych i - co istotne - stawiających wyjściową koncepcję w nowym świetle. W ciągu kolejnych 46 lat wydał nie mniej słynny $Z a-$ chodni kanon (1994) i książki, które go przygotowały (w tym Księge J z 1990),

${ }^{1}$ Określenie rozpowszechnione dzięki sztuce Dead White Males Davida Williamsona z 1995 roku.

2 Tytuł Sterling Professor - najwyższa pozycja przyznawana przez Yale University - funkcjonuje od 1918 roku, pierwszą kobietę uhonorowano nim w roku 1987, a obecnie (w 2020 roku) kobiety stanowią ok. 16\% tego grona. Por. The Sterling Professors of Yale: Evolution of a Species, „Yale News” 2011, https://yaledailynews.com/blog/2011/01/21/the-sterling-professors-of-yale-evolution-of-a-species/, dostęp: 5.10.2020.

${ }^{3}$ H. Bloom, Ksiegga J, tłum. B. Baran, Warszawa 2018; tenże, Jak czytać i po co, tłum. A. Kunicka, Warszawa 2019; tenże, Zachodni kanon. Książi i szkoła wieków, tłum. B. Baran, M. Szczubiałka, Warszawa 2019.

${ }^{4}$ Do literaturoznawczych analiz inspirowanych myślą Blooma - przede wszystkim dostępnym po polsku Lękiem przed wptywem - należą książki Magdaleny Bąk Twórczy lęk Stowackiego. Antagonizm wieszczów po latach (Katowice 2013) i Jana Potkańskiego Parabazy wptywu. Iwaszkiewicz, Bloom, Lacan (Warszawa 2008), a także wiele artykułów, między innymi: P. Bućko-Żmuda, "Ocalony, bo z nim wieczne i boskie zdziwienie”. Epilog burzliwego romansu wieszczów w kontekście teorii wplywu Harolda Blooma, „Postscriptum Polonistyczne” 2011, nr 1; P. Arbiszewska, „Lęk przed wptywem” wobec „Wielkiej improwizacji”, „Słupskie Prace Filologiczne” 2010, t. 8.

5 Wydanie polskie: H. Bloom, Lęk przed wptywem. Teoria poezji, tłum. A. Bielik-Robson, M. Szuster, Kraków 2002. 
oraz wiele takich, które zeń „wypączkowały” (jak Shakespeare: The Invention of the Human z 1998 czy Genius: A Mosaic of One Hundred Exemplary Creative Minds z 2002); kontynuowat prace teoretyczne (Agon: Towards a Theory of Revisionism z $1982 \mathrm{i}$ The Anatomy of Influence: Literature as a Way of Life z 2011), opracowywał antologie i krytyczne wydania kanonicznych dzieł, ale też rozwijał refleksję, którą można uznać za religioznawczą, choć przez samego Blooma jest nazywana raczej krytyką religijną (religious criticism na wzór literary criticism). Jej najważniejsze formy to Kabbalah and Criticism (1976), The American Religion: The Emergence of the Post-Christian Nation (1992), Omens of Millennium: The Gnosis of Angels, Dreams, and Resurrection (1996) i Jesus and Yahweh: The Names Divine (2005) ${ }^{6}$. Oryginalny sposób, w jaki Bloom łączył swoje zainteresowanie literaturą i religią, okazał się inspirujący dla co najmniej kilkorga polskich myślicieli, z Agatą Bielik-Robson i Adamem Lipszycem na czele 7 . Osobiście również cenię te jego poszukiwania, a do książek, które uważam za zasługujące na polskie tłumaczenie, zaliczam Ruin the Sacred Truths: Poetry and Belief from the Bible to the Present (1989).

Jak czytać i po co (2000) inaugurowało ostatni z nurtów twórczości Blooma, czyli pisarstwo kierowane do czytelnika nieprofesjonalnego. Wpisują się weń też Stories and Poems for Extremely Intelligent Children of All Ages („Opowiadania i wiersze dla wyjątkowo inteligentnych dzieci w każdym wieku", 2001) czy Where Shall Wisdom Be Found? („Skąd mądrości?”, 2004) ${ }^{8}$. Bloom jako „biblioterapeuta” (czy wręcz literacki „coach”) zdobył znaczną publiczność i poważnie rozszerzył swoje wpływy poza świat akademicki, co prowokuje do porównywania go z takimi autorami, jak Alain de Botton - twórca poradnika Jak Proust może zmienić twoje życie? . Na pytanie: „Po co czytać?” de Botton odpowiada zestawem życiowych maksym, które lektura klasycznego cyklu powieściowego

${ }^{6}$ Fragmenty niektórych spośród wymienionych książek ukazały się w poświęconym Bloomowi numerze „Literatury na Świecie” (2003, nr 9-10): Mapa przekrzywień, tłum. A. Lipszyc; Emerson: amerykańska religia, tłum. M. Szuster; Poetyckie przejścia, tłum. A. Lipszyc; Pomiar kanonu: "Mokre okna” i "Gobelin” Johna Ashbery'ego, tłum. M. Szuster; Amerykańska specyfika w poezji i krytyce, tłum. M. Szuster; Podzwonne dla kanonu, tłum. M. Szuster; Wolne i rozbite tablice. Kulturowe perspektywy amerykańskiego żydostwa, tłum. A. Lipszyc; Księga J: Jakub, tłum. A. Lipszyc; Do Freuda i dalej, tłum. A. Bielik-Robson.

A. Bielik-Robson, Podmiot jako akt woli. Harold Bloom i teoria dziedziczenia agonicznego, „Teksty Drugie” 1999, nr 1-2 (por. taż, The Saving Lie: Harold Bloom and Deconstruction, Illinois 2011); A. Lipszyc, Międzyludzie. Koncepcja podmiotowości w pismach Harolda Blooma z nieustającym odniesieniem do podmiotoburstwa, Kraków 2004.

${ }^{8}$ Podobny charakter ma ostatnia z książek Blooma, ukończona na kilka tygodni przed śmiercią, Take Arms Against a Sea of Troubles: The Power of the Reader's Mind over a Universe of Death, New Haven 2020 („Stawiać opór morzu nieszczęść. Władza czytelniczego umysłu nad domeną śmierci").

9 A. de Botton, Jak Proust może zmienić twoje życie, tłum. W. Sadkowski, Warszawa 2013. Pierwsze wydanie ukazało się w 1998 roku. De Botton jest również twórcą The School of Life instytucji oferującej więcej publikacji korzystających z dorobku światowej humanistyki, a także całe kursy na nich oparte. 
pozwala zinternalizować: ceń upływający czas, bądź uważna, unikaj schematów, dbaj o przyjaciół i staraj się nie wyrządzać krzywdy. Literatura jako narzędzie poprawy jakości życia przypomina w tej optyce software zalecany do instalacji na egzystencjalnym twardym dysku. Bloom idzie co najmniej o dwa kroki dalej w swojej odpowiedzi na to samo pytanie.

\section{Po co czytać i jak?}

Po pierwsze: literatura jest według niego zakodowana w innym języku niż ten, w którym upływa ludzka codzienność, przez co stawia opór prostej instrumentalizacji. Jej odbiór wymaga szczególnych kompetencji kulturowych, ale i duchowych, czyli zgody czytelnika na wieloznaczność świata i własną złożoność. Literatura - pisze Bloom:

nie jest po prostu językiem, lecz także wolą figuracji, motywacją do metafory, którą Nietzsche zdefiniował kiedyś jako pragnienie różnienia się, pragnienie bycia gdzie indziej. Oznacza to po części różnienie się od siebie, lecz przede wszystkim, jak sądzę, od metafor i obrazów przygodnych utworów będących dziedzictwem danego pisarza ${ }^{10}$.

Owo „pragnienie różnienia się”, cechujące twórców literatury, jest według Blooma podstawową motywacją również dla czytelników, korzystających z pomocy tekstów w trudnych zmaganiach o różnienie się od samych siebie. Praca nad jaźnią, jej „umocnienie" ${ }^{11}$, byłaby więc stawką literatury, przy czym chodzi o szczególnie rozumianą jaźń, złożoną z różnych instancji pozostających we wzajemnym dialogu, podważających się, ironizujących na swój temat itp. Rozpoznaniu i pogłębieniu tej aporetycznej jakości najlepiej według Blooma sprzyja poezja, jako najsprawniejsze urządzenie do „samopodsłuchiwania”. Wielowarstwowa antropologia Blooma, inspirowana gnozą i pismami Sigmunda Freuda, dodaje ważny argument za uczeniem się wierszy na pamięć: deklamując je z pamięci, wchodzimy na kolejny poziom samopodsłuchiwania: oprócz agonu różnych instancji poetyckich możemy bowiem wówczas obserwować także samych siebie udzielających im głosu, znających przyszły wynik relacjonowanych zmagań, a zarazem obserwujących je z czułego dystansu.

Utwory prozatorskie i dramaty według autora Zachodniego kanonu pozwalają natomiast śledzić artykulacje - z reguły bolesnych - aporii cechujących życie społeczne. I tak na przykład Kiedy umieram Williama Faulknera „katastroficznie portretuje kondycję ludzką z nuklearną rodziną jako najstraszniejszą

${ }^{10}$ H. Bloom, Zachodni kanon..., dz. cyt., s. 22.

11 Tenże, Jak czytać i po co, dz. cyt., s. 103. 
z katastrof” "12; Wielkie nadzieje Charlesa Dickensa celebrują „naszą dziecinną potrzebę miłości i odzyskania jej”, dając się czytać jako wehikuł powrotu „do domu, żeby uśmierzyć nasz ból”" Bloom ceni także dłuższe poematy narracyjne („Kocham Sir Patricka Spensa, ponieważ ma tragiczną ekonomię niemal unikalną w swoim stoickim heroizmie. Cały poemat przenika poczucie, że ten heroizm jest z konieczności autodestrukcyjny, a jednak pozostaje godny podziwu" $\left.{ }^{14}\right)$ i ballady, w których ironia równoważy patos ${ }^{15}$. Właśnie ironia do pary z metaforą to najważniejsze dla Blooma źródła mocy literatury, oręża w agonicznej walce pisarzy o wybitność i narzędzia władzy retorycznej pojętnych czytelników.

Po drugie: umacnianie ludzkiej jaźni dzięki przekraczaniu zastanej kondycji, jakie umożliwia literatura, ma dla Blooma wymiar religijny. Bloom wypracował oryginalne, złożone i wymagające uwagi rozumienie relacji między świeckim a świętym, na własnych warunkach rehabilitując pojęcia religijne jako narzędzia krytycznoliterackie i tym samym współtworząc zwrot postsekularny ${ }^{16}$. Poprzedzające literaturę „pragnienie bycia gdzie indziej” okazuje się w jego koncepcji tożsame z pragnieniem zbawienia, i to na trzy sposoby. (1) Jako gnostycki impuls samopoznania, prowadzący do wiedzy o obcości najgłębszych warstw jaźni wobec nieprzyjaznego jej świata. (2) Jako namiętność do tego, co inne (otherness), umożliwiająca „wyjście z pułapki śmiertelności”. Wychodząc poza siebie - przez pisanie bądź czytanie literatury - zyskujemy szansę na trwanie dłuższe czy chociaż szersze niż nasza skończona osoba. Najsilniejsi z autorów uzyskują bardziej radykalną formę zbawienia: nieśmiertelność. (3) Jako domaganie się (Boskiego?) błogosławieństwa „więcej życia!”, analogicznego do tego, jakiego dostąpił Jakub po wygranej walce z Aniołem. Jedynie w tym trzecim rozumieniu zbawienia Bloom sugeruje istnienie nadprzyrodzonej instancji, dysponującej mocą wyrwania człowieka z jego marnej kondycji i nagrodzenia w ten sposób jego (literackich) wysiłków.

Każda z tych religijnych konotacji wydaje się aktywna, gdy Bloom opisuje Marcela Prousta, osiągając poziom patosu z gruntu obcy retoryce de Bottona:

12 Tamże, s. 302.

13 Tamże, s. 199.

14 Tamże, s. 118.

15 Tamże, s. 121.

${ }^{16}$ Nieprzypadkowo to Agata Bielik-Robson, którą można uznać za jego uczennicę, zainaugurowała w Polsce podobny proces, publikując takie książki, jak Inna nowoczesność. Pytanie o wspótczesna formutę duchowości (Kraków 2000) czy Na pustyni. Kryptoteologie późnej nowoczesności (Kraków 2009). Na marginesie zaznaczę, że wspomniany wcześniej Alain de Botton traktuje religię podobnie utylitarnie jak literaturę, redukując pożytek z niej do kilku maksym nietrudnych do przyjęcia przez współczesnych, przyzwyczajonych do wygody konsumentów; zob. A. de Botton, Religia dla ateistów. Poradnik dla niewierzących, jak korzystać z religii, tłum. H. Pustuła-Lewicka, Warszawa 2013. 
Można wystrzegać się mylenia Prousta z Bhagawadgita, a jednak Proustowska pamięć ostatecznie leczy narratora i czytelnika z tego, przed czym ostrzega starożytne hinduistyczne dzieło jako przed „mroczną bezwładnością”. Czytamy powieści (największe), aby uleczyć mroczną bezwładność, chorobę na śmierć. Nasza rozpacz wymaga pociechy i lekarstwa głębokiej narracji ${ }^{17}$.

Proustowską ironię uznaje za „świecki odpowiednik głębokiej duchowości”18, a jego postacie nazywa „komicznymi geniuszami”, którzy „zapewniają nam możliwość uwierzenia, że prawda jest równie zabawna jak ponura"19. Takich religio-literaturoznawczych szarży w Jak czytać i po co jest więcej i nieraz olśniewają czytelnika. Autor Zachodniego kanonu zdaje się czynić własne pisarstwo wehikułem podobnej, tragikomicznej wizji egzystencji, jaką dostrzega u Prousta: operuje naprzemiennie w alegorycznym i ironicznym trybie interpretacji, każdorazowo zakładając, że między powierzchnią tekstu a tym, co w istocie przekazuje autor, jest zasadnicza nietożsamość, przy czym alegoryści proponują czytelnikowi określoną treść, ironiści zaś pozostawiają go bez pozytywnego projektu. Bloom oscyluje między tymi rejestrami, podobnie jak oscyluje między religijną wiarą i niewiarą, co ciekawie wybrzmiewa w epilogu Jak czytać i po co, będącym egzegezą jednej ze starożytnych Sentencji ojców. Rabbi Tarfon powiedział mianowicie: „Sam nie musisz wykonać do końca całej roboty, ale też nie wolno ci jej porzucić” ${ }^{20}$. Bloom próbuje wyczytać z tych słów pomoc dla siebie przy podejmowaniu „moralnych decyzji”, ale z premedytacja komplikuje ten proces, zestawiając Tarfona z ironizującym na ten sam temat Williamem Szekspirem (którego nazywa „świeckim Pismem”21) i zawieszając odpowiedź na pytanie, czy praca, którą w ciągu życia ma wykonać człowiek, jest jego własnym zobowiązaniem czy losem przeznaczonym mu przez bogów.

\section{Co czytać?}

Funkcje, jakie Bloom przypisywał literaturze, zadecydowały o jakościach kwalifikujących teksty artystyczne do Zachodniego kanonu, takich jak oryginalność, niesamowita dziwność, ambiwalentna ironiczność. Ta klasyczna już pozycja okazuje się jednak nie tylko wypowiedzią o literaturze, lecz także o samej idei kanonu. Dlaczego stała się dla Blooma taka ważna? I czy jego propozycja - przy wszystkich zastrzeżeniach, jakie budzi - jest warta naszej uwagi?

${ }^{17}$ H. Bloom, Jak czytać i po co, dz. cyt., s. 222.

18 Tamże.

19 Tamże, s. 223.

20 Tamże, s. 343.

${ }^{21}$ Tamże, s. 350. 
Na pierwsze z tych pytań można odpowiedzieć: skoro stawką literatury jest zbawienie, szkoda życia na czytanie złych książek. W tej perspektywie Bloom promuje kanon jako narzędzie wspólnej troski o głębię poszczególnych jaźni, nazywa go „kapłanem śmierci”22. W zgodzie z tak poważnym traktowaniem tej idei pozostaje decyzja krytyka, by przez projekt Księgi $J$ - w którym spekuluje na temat autorki części Biblii hebrajskiej - włączyć świętą księgę judaizmu i chrześcijaństwa do świeckiego kanonu literackiego, a przez to odsłonić umowność podziału na teksty święte i świeckie oraz ambiwalencję tkwiąca w samej koncepcji kanonu, być może nieuchronnie religijnej.

Kanoniczność to także etykieta potrzebna Bloomowi na określenie szczególnej jakości wytwarzanej w agonicznych walkach piszących: to dzięki konkurowaniu o przetrwanie w ludzkiej pamięci, twierdzi krytyk, autorzy osiagają estetyczną wybitność. Pochodną tego mechanizmu bywa potrzeba znajomości szerokiej sieci wzajemnych literackich wpływów (na przykład by docenić głębię Hermana Melvilla, trzeba znać Szekspira). To jedna z przyczyn, dla których Bloom wszedł w tak silny konflikt z uczniami Michela Foucaulta, domagającymi się otwarcia kanonu. Według amerykańskiego krytyka życie jest za krótkie, żeby czytać książki pomniejszych pisarzy, a dawanie głosu mniejszościom to rola innych instytucji niż literaturoznawstwo. Społeczeństwo interesuje go jedynie o tyle, o ile stawia opór jednostce ${ }^{23}$.

Trudno jednak myśleć o kanonie w oderwaniu od społecznego kontekstu, w którym jest tworzony. Największa słabość, na którą wskazują krytycy Blooma, wiąże się z niemożnością pogodzenia jego elitarystycznego myślenia o literaturze z postulatami demokratycznymi. Zalecając ludziom czytanie jako narzędzie „do zbawienia koniecznie potrzebne”, Bloom ignoruje fakt, że społeczeństwa powszechnie czytającego nigdy nie było i prawdopodobnie nie może być, dopóki podział pracy wiąże się z różnicami w edukacji i wynagrodzeniu, przekładającymi się na odmienne kultury czasu wolnego i upodobania czytelnicze (na przykład cykl książek o Harrym Potterze według niego w ogóle nie zasługuje na miano literatury ${ }^{24}$ ). Mówiąc, że bez dobrej („kanonicznej”) lektury, dostarczającej zasobów pamięci, idei i wyobrażeń, ludzie nie umieją myśleć, krytyk deprecjonuje sporą część społeczeństwa inaczej wyrażającą swoje doświadczenia i ambicje.

Kolejny problem to fakt, że autor The American Religion prezentuje jako uniwersalną motywację czytania to, co jest pochodną jego szczególnej kondycji.

${ }^{22}$ H. Bloom, Zachodni kanon..., dz. cyt., s. 43.

${ }^{23}$ Podobnie jak jedną z niewielu cenionych przez niego kobiet, Jane Austen, która - jak czytamy - „jest zbyt inteligentna, żeby nie wiedzieć, iż duża część rzeczywistości społecznej nie wytrzyma wnikliwej analizy, lecz dla niej porządek społeczny jest czymś danym, czymś, co trzeba przyjąć, żeby móc opowiedzieć swoje historie”. Tenże, Jak czytać i po co, dz. cyt., s. 187.

${ }_{24}$ Por. Harold Bloom Interview on Harry Potter, the Internet and More, 2000, https://www. youtube.com/watch?v=EVWiwd0P0c0\&t=513s\&ab_channel=ManufacturingIntellect, dostęp: 26.10 .2020 . 
Za przykład niech posłuży jego komentarz do Ulissesa Alfreda Tennysona: „jakże wspaniały wyraz pamiętnego niezadowolenia stanowi te pięć otwierających wersów! Iluż starzejących się mężczyzn przez stulecia rozmyślało właśnie w tym duchu” ${ }^{25}$. Można się wraz z autorem cieszyć z tego, że przeżycia starzejącego się mężczyzny znalazły tak świetny literacki wyraz, trudno jednak nie być zaskoczonym, gdy w innym miejscu tej samej książki podkreśla, że pisarstwo kobiet nie jest interesujące jako takie, a jedynie o tyle, o ile ciekawie dialoguje z twórczością Szekspira (Jane Austen), czy gdy odsłania uniwersalne mechanizmy samopoznania (Emily Dickinson). Szkoda, że wybitne literackie artykulacje doświadczenia związanego na przykład z macierzyństwem nie zasłużyły na obecność w kanonie (charakterystyczne, że z pisarstwa Toni Morrison krytyk preferuje Pieśń Salomonowa kosztem Umitowanej).

\section{Harold Bloom a sprawa polska}

I wreszcie trzeci z zarzutów, jakie prowokuje idea kanonu w ujęciu Blooma: oferując listę książek, na jakie warto poświęcić swój ograniczony czas, krytyk zdaje się zapominać o tożsamościowej funkcji literatury w skali narodowej. Albo inaczej: pamięta o niej, lecz stronniczo, wyraźnie uprzywilejowując literaturę anglojęzyczną, którą określa mianem „naszej” i ilościowo nadreprezentuje. Obecność niektórych książek w kanonie ma uzasadniać to, że pozwalają zrozumieć współczesną Amerykę ${ }^{26}$. Gdzie jednak szukać pomocy, jeśli przez literaturę chcemy zrozumieć inne kraje? Czy jako Polka istotnie więcej skorzystam na lekturze Melville’a niż Adama Mickiewicza?

Poświęcając wiele uwagi idei kanonu, Bloom nie zdecydował się wytłumaczyć znaczenia drugiego członu tytułu swej słynnej książki. Czym jest Zachód?

${ }^{25}$ H. Bloom, Jak czytać i po co, dz. cyt., s. 86. Charakterystyczny (choć znacznie bardziej inkluzywny) jest też następujący fragment: „Rzadko poezja może pomóc nam w obcowaniu z innymi; to piękny idealizm, z wyjątkiem pewnych dziwnych momentów, jak chwila zakochania się. Samotność jest częstszym znamieniem naszej kondycji - jak mamy zaludnić tę samotność? Wiersze mogą nam pomóc mówić do siebie jaśniej i pełniej oraz podsłuchiwać to mówienie", tamże, s. 91. Samotność, o której pisze Bloom, wydaje się czymś więcej niż powszechną kondycją wynikającą z ograniczeń języka - także fizyczną izolacją i ograniczonym dostępem do ludzi różnych od siebie, właściwymi wysokiej kadrze profesorskiej przebywającej niemal wyłącznie na kampusach.

${ }^{26} \mathrm{Na}$ przykład Raj utracony Johna Miltona miałby pozwalać dojrzeć protestancki rdzeń współczesnej kultury amerykańskiej: „Milton jest równie fundamentalnym poetą protestanckim, jak Dante jest głównym poetą-prorokiem katolicyzmu. Nasza kultura i wrażliwość, nawet nasza religia w Stanach Zjednoczonych są pod wieloma subtelnymi względami bardziej postprotestanckie niż protestanckie, jednak z trudem zdołamy ją pojąć bez jakiegoś jasnego wyczucia protestanckiego ducha. Ten duch osiągnął apoteozę w Raju utraconym, a śmiałemu czytelnikowi warto doradzać stawienie czoła trudnościom”, tamże, s. 141. 
Na długiej liście dzieł kanonicznych znajdziemy utwory ze wszystkich kontynentów, powstałe w różnych językach. Polszczyznę reprezentują: Bruno Schulz, Czesław Miłosz, Witold Gombrowicz, Stanisław Lem, Zbigniew Herbert i Adam Zagajewski. O ile mi wiadomo, nie istnieje żaden komentarz Blooma do tego wyboru ani do żadnego z wymienionych utworów, możemy więc jedynie spekulować na temat przyjętych kryteriów. Taką próbę podejmuje Adam Czerniawski:

On po prostu nie zna naszej literatury, zaledwie tych kilka nazwisk obiło mu się o uszy. Naturalnie nie można go winić za to, że jej nie zna, bo wszystkiego wiedzieć nie może, ale można za to, że udaje, że wszystko wie. Do kanonu wcisnął prawie całą brytyjską poezję XIX wieku, a więc wedle takich kryteriów zmieściłby się tam nie tylko Mickiewicz, Słowacki i Norwid, ale także Malczewski, Lenartowicz i Asnyk ${ }^{27}$.

Zgoda, literatury polskiej jest w kanonie Blooma niewiele, i to zarówno w porównaniu z brytyjską, jak i na przykład jidysz. Nietrudno skojarzyć to z wiedzą, że jidysz był pierwszym językiem krytyka, angielski zaś tym, którym posługiwał się przez większość życia. Można mu zatem zarzucać (znów) uniwersalizację osobistej perspektywy i kolonializm, skoro to język imperium jest dla niego podstawową miarą hierarchii. Bardziej konstruktywne wydaje się jednak zastanawianie, jak wyglądałby kanon literatury polskiej, gdyby przyjąć te kryteria Blooma, które lepiej wytrzymują krytykę.

To temat ważny także w kontekście reformowanego wciąż programu narodowej edukacji i postulatu umiędzynarodowienia nauki, w tym humanistyki, jaki w ostatnich latach coraz częściej u nas wybrzmiewa. Idąc tropem Blooma, dla celów edukacji szkolnej należałoby zidentyfikować polskiego Szekspira i wybrać autorów, którym udaje się wywalczyć wielkość w zmaganiach z nim (aktualna lista lektur częściowo podąża w tym kierunku, doceniając Kochanowskiego, Mickiewicza, Wyspiańskiego i Gombrowicza, choć słabsza jest obecność Miłosza, logicznie uzupełniającego ten szereg ${ }^{28}$ ). Drugim kryterium byłaby osiagana bardziej niezależnie szczególna „dziwność” czy „swojska obcośc” języka autorów

${ }^{27}$ Hierarchie, kanony, wartości. Z Adamem Czerniawskim rozmawia Piotr Wilczek, „Opcje” 2001, nr 5, s. 34; cyt. za: J. Hniduk, Co tam panie w Ameryce - o recepcji poezji Adama Zagajewskiego w Stanach Zjednoczonych, „Teksty Drugie” 2010, nr 3, s. 192.

${ }^{28}$ Odnoszę się do aktualnej Listy lektur obowiązkowych („z gwiazdką”) do matury z języka polskiego na poziomie podstawowym (od $2015 \mathrm{roku}$ ), por. https://cke.gov.pl/egzamin-maturalny/, dostęp: 26.10.2020. Do najważniejszych powojennych prób konstruowania podobnych kanonów literatury polskiej, koncentrujących się wokół najsilniejszych autorów, należą antologie krytyczne Artura Sandauera (Poeci trzech pokoleń, Warszawa 1955 i Poeci czterech pokoleń, Kraków 1977), słynny esej Jana Błońskiego Bieguny poezji ([w:] tegoż, Odmarsz, Kraków 1978) czy podręcznikowe opracowanie Michała Pawła Markowskiego Polska literatura nowoczesna. Leśmian, Schulz, Witkacy, Kraków 2007 (autor we wstępie zaznacza, że do listy kanonicznych pisarzy polskiego modernizmu zalicza też Witolda Gombrowicza, któremu poświęcił osobną książkę Czarny nurt. Gombrowicz, świat, literatura, Kraków 2004). 
kanonicznych, właściwa choćby Schulzowi, zgodnie wymienianemu przez Blooma i Centralną Komisję Egzaminacyjną. I tu możemy przejść do pytania o warunki umiędzynarodowienia szerszego zestawu polskich twórców i twórczyń. Odpowiedzią mogłoby być określenie grona tych, którzy mogą wesprzeć czytelnika w umacnianiu własnej jaźni, podsłuchiwaniu dialogowania jej mnogich instancji, uczeniu się komunikowania z obcością w nas i poza nami, przekraczaniu skończoności w czasie i przestrzeni; słowem, w nauce (powiększonego) życia i (samotnego) umierania, bo to jest ostatecznie stawka literatury w Bloomowskiej „szkole wieków”. Podobne poszukiwania prowadzono w niedawno wydanych historiach literatury polskiej pisanych z myślą o odbiorcy zagranicznym, choć ich optyka poważnie się od Bloomowskiej różni ${ }^{29}$. Zwłaszcza Being Poland reprezentuje literaturoznawstwo, które w zakres swoich powinności włącza refleksję nad literaturą jako instytucją życia społecznego, a nie tylko ocenianie wartości estetycznej książek i interpretowanie ich, do czego ogranicza się wizja tej dyscypliny, jaką proponuje autor Lęku przed wptywem.

\section{Czytanie Blooma}

Cechujące Blooma erudycja literacka i wrażliwość na wielopoziomowość znaczeń, jakie rozgrywają na kartach swych dzieł kanoniczni twórcy, nie pozostały bez wpływu na jakość jego pisarstwa. Można go satysfakcjonująco czytać w perspektywie jego własnej teorii, jako krytyka walczącego o wielkość z prekursorami, zarówno jawnymi (jak Samuel Johnson, William Hazlitt czy Northrop Frye), jak i ukrytymi, wśród których można by wymienić niejednego dekonstrukcjonistę i niejedną feministkę - trudno bowiem wyobrazić sobie Zachodni kanon, gdyby nie te nurty w teorii literatury. Powstanie tej książki było formą sprzeciwu Blooma wobec wpływu „szkoły resentymentu” na nauczanie i badania uniwersyteckie - i gra o tę szczególną stawkę jest przez niego rozgrywana na każdym kroku (na własnym boisku) ${ }^{30}$. Jak zauważa Tomasz Kitliński w artykule Humanizm po antyhumanizmie - w którym zestawia Blooma z Marią Janion, Julią Kristevą i Marthą C. Nussbaum ${ }^{31}$ - należy on do myślicieli, którzy

29 Zob. Being Poland: A New History of Polish Literature and Culture, red. T. Trojanowska, J. Nizyńska, P. Czapliński, Toronto 2018 i Światowa historia literatury polskiej. Interpretacje, red. M. Popiel, T. Bilczewski, S. Bill, Kraków 2020.

${ }^{30}$ Za przykład tej strategii niech posłuży fragment interpretacji Szekspirowskiego Króla Leara: „Wybitny charakter sztuki wszystko zawdzięcza patriarchalnej wielkości Leara, temu aspektowi człowieczeństwa dziś tak powszechnie zdewaluowanemu w krytycznej epoce feminizmu, literackiego marksizmu i różnych pokrewnych odmian sprowadzanej przez nas z Paryża antymieszczańskiej krucjaty", H. Bloom, Jak czytać i po co, dz. cyt., s. 82.

${ }^{31}$ T. Kitliński, Humanizm po antyhumanizmie. Myśl Marii Janion, Julii Kristevej, Martby C. Nussbaum i Harolda Blooma, „Studia Etyczne i Estetyczne” 2003, t. 6. W podobnym 
odrobili lekcję dekonstrukcji i idą „trzecią drogą”, pomiędzy konserwatywnym, mocnym ujęciem podmiotowości a jej postmodernistycznym zakwestionowaniem, wyznając „wychylony ku obcości” humanizm ${ }^{32}$.

Można go też czytać jako teoretyka literatury, podejmującego poważny namysł nad jej aktualnymi funkcjami i od jego wyników uzależniającego swą praktykę krytyczną. Bloom wyżej ceni możliwości literatury jako przewodniczki duchowej współczesnego człowieka niż ofertę filozofii, religii czy psychologii. To przede wszystkim literatura uczy poznania i „uznawania zmiany, w sobie i w innych, nawet finalnej formy zmiany" (czyli śmierci). Uprawiane przez niego gnostyckie literaturoznawstwo chciało być adekwatne do swoich czasów i sądzę, że istotnie było - i przez dłuższy czas pozostanie - atrakcyjną odpowiedzią na realne potrzeby.

Jest jeszcze jeden możliwy tryb lektury obu wydanych niedawno przez Aletheię książek Blooma: pozwalają sprawniej rozmawiać o tekstach, których się nie czytało ${ }^{33}$. To jeden z momentów ironicznych jego książek: choć głoszą pochwałę samotnej, transformującej, najlepiej wielokrotnej lektury kanonicznych tekstów w całości (na przykład po to, by zdążyć zakochać się w ich bohaterach czy rozpoznać głębię tragizmu ich losów), świetnie się nadają do tego, żeby za ich pomocą niewielkim kosztem uzyskać tak pożądaną społecznie orientację we wspólnej bibliotece, będącej raczej wytrychem do przestrzeni kulturalnej elity niż wąską ścieżką dla wybranych, u kresu której mogą dosięgnąć Błogosławieństwa. Jeśli książki Blooma są kanoniczne nie tylko w potocznym sensie - wypada je znać, bo napisał je człowiek wpływowy, a w dodatku są przydatne w dydaktyce i jako punkt odniesienia dyskusji - a także w tym szczególnym, mocnym sensie, którego on sam jest autorem, powinny wytrzymać próbę również takiej lektury, pozostając ambiwalentnie ironiczne względem własnego znaczenia (które jest zawsze „wędrującym banitą”, powiada Bloom).

duchu myśl Blooma interpretuje Tomasz Garbol, zestawiając go z innymi teoretykami twórczo kontynuującymi romantyczną refleksję nad literaturą w artykule Subtelniejsze języki refleksji nad relacja: literatura a religia. Meyer Howard Abrams, Harold Bloom i Geoffrey Hartman [w:] Literatura i religia - wyzwania epoki świeckiej, t. 1: Teorie i metody, red. Ł. Tischner, T. Garbol, Kraków 2020.

32 T. Kitliński, dz. cyt., s. 148.

33 Por. P. Bayard, Jak rozmawiać o książkach, których się nie czytato?, tłum. M. Kowalska, Warszawa 2008. 


\section{Bibliografia}

Arbiszewska P., „Lęk przed wptywem” wobec „Wielkiej improwizacji”, „Słupskie Prace Filologiczne" 2010, t. 8.

Bayard P., Jak rozmawiać o ksiązkach, których się nie czytato?, tłum. M. Kowalska, Warszawa 2008.

Bąk M., Twórczy lęk Stowackiego. Antagonizm wieszczów po latach, Katowice 2013.

Being Poland: A New History of Polish Literature and Culture, red. T. Trojanowska, J. Nizyńska, P. Czapliński, Toronto 2018.

Bielik-Robson A., Inna nowoczesność. Pytanie o wspótczesna formute duchowości, Kraków 2000.

Bielik-Robson A., Na pustyni. Kryptoteologie późnej nowoczesności, Kraków 2009.

Bielik-Robson A., Podmiot jako akt woli. Harold Bloom i teoria dziedziczenia agonicznego, „Teksty Drugie” 1999, nr 1-2.

Bielik-Robson A., The Saving Lie: Harold Bloom and Deconstruction, Illinois 2011.

Bloom H., Jak czytać i po co, tłum. A. Kunicka, Warszawa 2019.

Bloom H., Ksiega J, tłum. B. Baran, Warszawa 2018.

Bloom H., Lęk przed wptywem. Teoria poezji, tłum. A. Bielik-Robson, M. Szuster, Kraków 2002.

Bloom H., Take Arms Against a Sea of Troubles: The Power of the Reader's Mind over a Universe of Death, New Haven 2020.

Bloom H., Zachodni kanon. Książki i szkota wieków, tłum. B. Baran, M. Szczubiałka, Warszawa 2019.

Błoński J., Bieguny poezji [w:] tegoż, Odmarsz, Kraków 1978.

Botton de A., Jak Proust może zmienić twoje życie, tłum. W. Sadkowski, Warszawa 2013.

Botton de A., Religia dla ateistów. Poradnik dla niewierzących, jak korzystać z religii, tłum. H. Pustuła-Lewicka, Warszawa 2013.

Bućko-Żmuda P., „Ocalony, bo z nim wieczne i boskie zdziwienie”. Epilog burzliwego romansu wieszczów w kontekście teorii wptywu Harolda Blooma, „Postscriptum Polonistyczne" 2011, nr 1.

Garbol T., Subtelniejsze języki refleksji nad relacją: literatura a religia. Meyer Howard Abrams, Harold Bloom i Geoffrey Hartman [w:] Literatura i religia - wyzwania epoki świeckiej, t. 1: Teorie i metody, red. Ł. Tischner, T. Garbol, Kraków 2020.

Harold Bloom Interview on Harry Potter, the Internet and More, 2000, https://www. youtube.com/watch?v=EVWiwd0P0c0\&t=513s\&ab_channel=ManufacturingIntellect, dostęp: 26.10.2020.

Hierarchie, kanony, wartości. Z A. Czerniawskim rozmawia P. Wilczek, „Opcje” 2001, nr 5.

Hniduk J., Co tam panie w Ameryce - o recepcji poezji Adama Zagajewskiego w Stanach Zjednoczonych, „Teksty Drugie” 2010, nr 3.

Kitliński T., Humanizm po antyhumanizmie. Myśl Marii Janion, Julii Kristevej, Marthy C. Nussbaum i Harolda Blooma, „Studia Etyczne i Estetyczne” 2003, t. 6. 
Lipszyc A., Międzyludzie. Koncepcja podmiotowości w pismach Harolda Blooma $z$ nieustającym odniesieniem do podmiotoburstwa, Kraków 2004.

Lista lektur obowiązkowych do matury z języka polskiego na poziomie podstawowym, https://cke.gov.pl/egzamin-maturalny/, dostęp 26.10.2020.

„Literatura na Świecie” 2003, nr 9-10.

Markowski M.P., Czarny nurt. Gombrowicz, świat, literatura, Kraków 2004.

Markowski M.P., Polska literatura nowoczesna. Leśmian, Schulz, Witkacy, Kraków 2007.

Potkański J., Parabazy wptywu. Iwaszkiewicz, Bloom, Lacan, Warszawa 2008.

Sandauer A., Poeci czterech pokoleń, Kraków 1977.

Sandauer A., Poeci trzech pokoleń, Warszawa 1955.

Światowa historia literatury polskiej, red. M. Popiel, T. Bilczewski, S. Bill, Kraków 2020.

The Sterling Professors of Yale: Evolution of a Species, „Yale News” 2011, https://yaledailynews.com/blog/2011/01/21/the-sterling-professors-of-yale-evolution-ofa-species/, dostęp: 5.10.2020. 